\section{Visión Electrónica Más que un estado sólido \\ https://doi.org/10.14483/issn.2248-4728}

UNIVERSIDAD DISTRITAL

FRANCISCO JOSÉ DE CALDAS

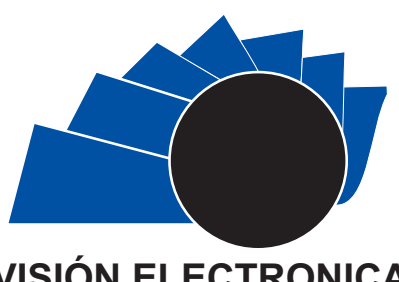

A Case-Study Vision

\title{
Video games sale control
}

\author{
Control de venta de video juegos
}

Miguel Angel Montaña Gutiérrez ${ }^{1}$

INFORMACIÓN DEL ARTICULO

Historia del articulo

Enviado: 17/10/2018

Recibido: 02/11/2018

Aceptado: 05/12/2018

Keywords:

Age,

Algorithm,

Control,

MATLAB,

Recognition,

Software.

\section{Palabras clave:}

Edad,

Algoritmo,

Control,

MATLAB,

Reconocimiento,

Software.

\section{ABSTRACT}

In this document it can be seen the methodology and the project's principal functioning; it will be taken as main support the ESRB classification, who is the Entertainment Software Rating Board, this as the theoretical part. In software it was used MATLAB as principal tool, together to a TOOLBOX of MathWorks geometry recognition; thanks to this it was possible control the sale to underage people and even adults (because something videogames have restrictions for people under 21 years old), this control only works with the creator of this project there was a time limitation, but it is expected to be able to expand the ages recognition. Despite of article's title "Video Games sale control" this one can be do a control more exhaustive of the products sale with age limitation.

\section{RESUMEN:}

En este documento se puede ver la metodología y el funcionamiento principal del proyecto; se tomará como soporte principal la clasificación ESRB, que es la Junta de Clasificación de Software de Entretenimiento, esto como parte teórica. En el software se utilizó MATLAB como herramienta principal, junto con un TOOLBOX de reconocimiento de geometría de MathWorks; Gracias a esto, fue posible controlar la venta a personas menores de edad e incluso a adultos (porque algunos de los videojuegos tienen restricciones para personas menores de 21 años), este control solo funciona con el creador de este proyecto; hubo una limitación de tiempo, pero se espera que sea capaz de ampliar el reconocimiento de las edades. A pesar del título del artículo "Control de venta de video juegos", este puede ser un control más exhaustivo de la venta de productos con limitación de edad.

\footnotetext{
${ }^{1}$ BSc In Mechatronics Engineering, Universidad Piloto de Colombia, Colombia. Current position: Universidad Piloto de Colombia, Colombia. E-mail: miguel-montana@,upc.edu.co. ORCID: https://orcid.org/0000-0001-8057-7157. 


\section{Introduction}

In the actual world exist many problems around the violence that is attributed to the videogames and even though it is not confirmed in a one hundred percent. There are many children who buy many video games, but these video games have a classification that, which by my experience, I know that they are not respected, for this reason there are children of ten or fifteen-yearold playing video games that are for people over eighteen and even twenty-one years of age, therefore we look for control the sale of these and contribute a little bit with this problem that we see today.

\section{Methods}

\subsection{Image processing}

The University School of Technical Telecommunications Engineering and the Polytechnic University of Madrid develop a final project where explains the description, MATLAB's toolbox of image processing, which improvement and facilitates the process's control. MATLAB provides to your users a platform calls MathWorks, here many professionals that works with MATLAB share they knowledge, for this case, it talks about recognition, tracing, comparison of objects, faces and others. Also, this page provides us an explanation clear about these codes and gives the link to download them. Using tools such as YouTube, it was possible to check the functioning of the camera both of computer and the application before changing it to the ip. Also, through this were seen tutorials about the ip, and how their connection with MATLAB works [1]. Also, other articles were very useful to understand this concept for example the Google's Could Vision. [2-3]

The Polytechnic University of Madrid wrote about the acquisition of images and graphical environments where we can see how step by step describe the main points of this process as: the complete installation of the camera to use or update the drivers and have updated the camera directly from the computer to verify the correct functioning. The code or instructions necessary to obtain the camera image, that there is no delay and to receive the maximum resolution of this, so that there is less loss of data. The next thing is to create a video object so that you can have it for different tasks. Then an online video channel is made and so you can calibrate all the necessary options of the camera. Next, we continue with the properties of video signal acquisition, thus we can calibrate certain predetermined properties of image acquisition. having all the above ready, we proceed to the data acquisition, with three simple steps, initialize the video object, configure the data capture (shot) and convert these data into images. Finally, this same document provides certain help at the level of graphical interface and useful code for the segmentation and preprocessing of images. [4]

Last, but not least, a lot of MATHWORKS documentation was used, since it has all the updated and functional MATLAB codes.

\subsection{Use of the camera}

The connection of the front camera of the Smart phone with the computer was made through the DroidCamX application; This allows us to make a wireless connection between the cell phone camera (with a live signal) and the application on the PC, this is very useful for us since the data capture of the video games was carried out satisfactorily thanks to the high quality of the Smart phone camera. [4]

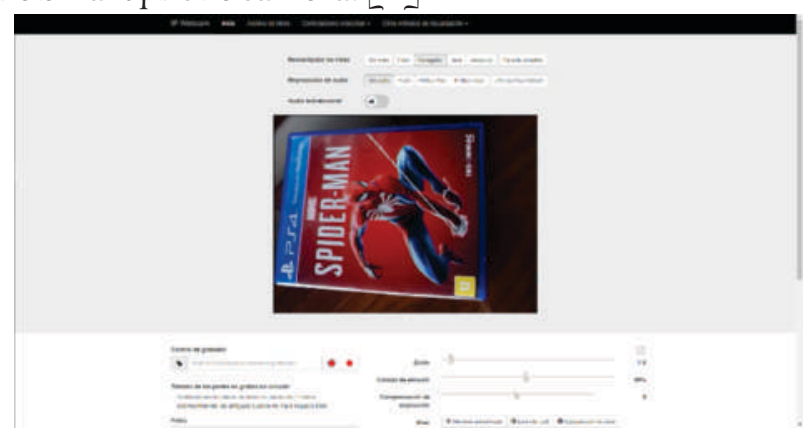

Figure 1. Connection sample and IP Webcam operation. Function between smartphone and server online (on PC). Source: own.

During the process that was carried out, the application had to be changed, by IP Webcam which is very similar to the previous one, having as main difference a better functioning for the free version of this, it also does not work for an external application in pc, on the contrary it works by means of the ip that is managed in the $\mathrm{Wi}-\mathrm{Fi}$ of the place and therefore, all you have to do is put the URL, what facilitates application permissions and connection problems between them, but it has the problem that when there is no Internet connection the program will fail.

\section{Development}

The process that was carried out for the taking of the database and other items in the work are the following:

-Data collection: The data collection was made for two specific objects which are: video games and my id card. 
This data collection was made with the camera of my Smart phone (which has $21 \mathrm{MP}$ ). At the videogame level, 6 games were chosen, of different platforms and features, with a total of 20 images per game. And for the id card a total of 26 photos were taken, having 13 on one side and 13 on the other.

-Prototype construction: The construction of the prototype is based on the capture of the complete image of the video game cover and thus have a controlled environment of light, avoiding contact with external light. Also, for this delivery we worked without prototype to give a wider field at the level of use, that probably not everyone can access the prototype or space is not available. The program was tested and modified so that the game and the id card can be recognized in an uncontrolled environment.

-Inclusion of the camera: We proceeded to get the professional version of the application for both $\mathrm{PC}$ and Android. The download of the drivers, the installation and configuration of said software were made. For the new application it is required to configure the ip that was handled in the place of the tests.

\subsection{Code}

In the above mentioned is the pre-processing and segmentation of the image, in which the pre-process is almost null, since the program works both in controlled environment and in one without control, obviously in a controlled environment the errors become almost null, but for this delivery we worked almost 100 percent in an uncontrolled environment, mainly it was about being careful with light, but it does not directly affect the tests. On the segmentation, it is done at the moment of finding the geometry in the image since, you must go to grayscale, so that the program in this way can recognize changes in the right way by having the image in two dimensions, this is done with both the captured image of the video and the database. [5] The code is divided into 2 phases:

Video capture: It was used as previously named, the function of MATLAB to read a URL, and transmit through it the video that is provided by means of the cell phone camera, analyze this video, and at the same time, it can take an exact frame which, is saved since, later it is used again for comparison; in the graphical interface, the video is shown, the image that is captured as much of the games as of the id card and also a box is available to modify the URL, since it depends on the place the url changes with respect to the previous one. [4], [6-7]

Comparison: Thanks to the document provided by MathWorks, this comparison could be made at a much more accurate level, thanks to the corners recognition, rough frames of the image, both the database and the one obtained from the video, all this thanks to instructions based on geometry, For this code in particular the number of points to be identified was increased from 25 by default, to 100 , in this way the comparison will be much more accurate since, the program recognizes where the original image (database) is located, comparing it with the one that is taken from the video, in the part of the graphic interface. [8] When doing the search in the database, haciendo una comparación con la imagen tomada, the selection of the most relevant points is made and it shows us a green box in the exact point where the similarity of the database is with the original, in case of not showing anything or showing a black line means that the similarity is minimal or does not exist. [5], [9]

\section{Results and discussion}

For the final part of this project, the problem was limited, being the only objective to ensure that the comparison between the game and the database is limited only to the ESRB code, so that, no matter the game, the moment it went on sale, the platform, even the country or continent, can be recognized without any problem the classification of this, Of course, it is based on the ESRB (Entertainment System Rating Board). [7]

With this we have that the program is divided into 3 sections: the capture part, videogame recognition and recognition for the id card.

Capture: It is in which the IP of the camera to be used is entered, using the IP webcam application, then, one of the 2 options is selected, both capture the game and the id card to continue with the next 2 sections.

Videogame recognition: With the previously captured image, recognition is proceeded, in this, the program identifies the key points of the image (ESRB code) of the game and compares it with the database, which consists of 12 photos, having 3 photos of each category to use $(\mathrm{E}, \mathrm{E}+10, \mathrm{~T}, \mathrm{M})$ that will be explained later. 


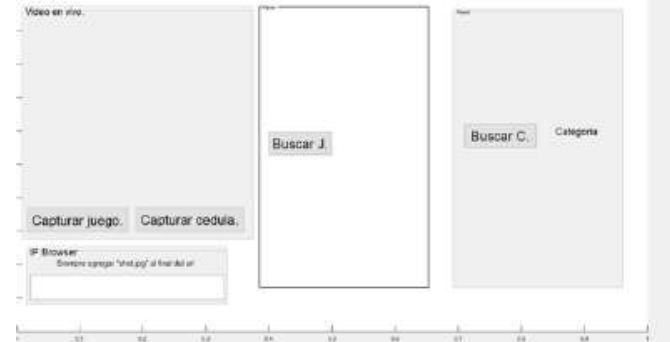

Figure 2. Interface of the program designed in MATLAB. Source: own.

The comparison is done in real time, considering the number of coincidences (what can exceed the set number of points for the command SURF), in this case, 20 coincidences were established. Thus, depending on which cycle shows more similarities, it will show us which one had the most coincidences, which are:

-1 to $3, \mathrm{E}+10$.

-4 to $6, \mathrm{E}$.

-7 to $9, \mathrm{M}$

-10 to $12, \mathrm{~T}$

Having already the corresponding classification, will give us a short description of this classification, in addition to placing an image in good resolution of this classification, so the viewer or user can confirm that the procedure was satisfactory.

Identity document recognition: Having the image captured from the first step, continue to place the capital letter of the classification that appeared in the previous step (video game recognition), the comparison with the database is done in the same way as videogames, but in this case the database is of 6 photos, all the identity card, which also follows a cycle, in the following way:

- 13 to 15 , id card (under-age).

- 16 to 18 , ID card (adult).

In this case, if you give us the first cycle, tells us what restrictions exist for the ID card (adult) and for an id card (under-age), will give us the same information and an image authorizing or denying the purchase. Having the following restrictions:

- E: Content is generally suitable for all ages. May contain minimal cartoon, fantasy or mild violence and/or infrequent use of mild language. [10]

$-\mathrm{E}+10$ : Content is generally suitable for ages 10 and up. May contain more cartoon, fantasy or mild violence, mild language and/or minimal suggestive themes. [10]

- T: Content is generally suitable for ages 13 and up. May contain violence, suggestive themes, crude humor, minimal blood, simulated gambling and/or infrequent use of strong language. [10]

- M: Content is generally suitable for ages 17 and up. May contain intense violence, blood and gore, sexual content and/or strong language. [10]

For this case we have an established number of 100 matches.

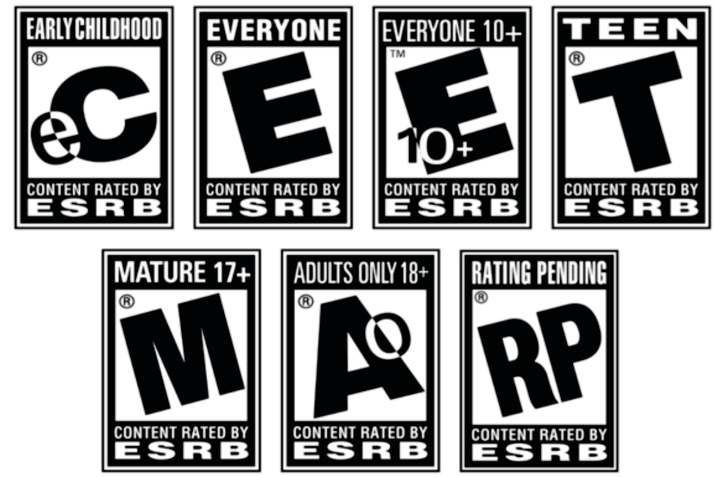

Figure 3. ESRB code [10].

\section{Conclusions}

We can conclude that the project can have a wide field of work, we can conclude that the project can have a wide field of work, since, to verify the correct functioning of this, in the test stage several objects were used to verify whether it recognizes something that has not been designated, or that it can recognize different previously selected objects.

With this work, the uncontrolled sale of video games to minors can be greatly limited.

The field of work at the physical level is incredibly high, even working with a computer camera, cell phone or other there will be no problem, In the same way, the part that records the camera can have light control or none, if there is a light source, and nothing interferes with the camera's focus

\section{References}

[1] Matemática Aplicada, "Procesamiento de imágenes digitales”, 2018. [Online]. Available at: http://asignatura.us.es/imagendigital.

[2] CampusMVP, "Google presenta su API de 
reconocimiento de imágenes con inteligencia artificial”, 2015. [Online]. Available at: https://www.campusmvp.es/recursos/post/ Google-presenta-su-API-de-reconocimientode-imagenes-con-inteligencia-artificial.aspx.

[3] Google Cloud, "Potente análisis de imágenes", 2017 . [Online]. Available at: https://cloud.google.com/vision/

[4] A. Manna, "Introducción al Procesamiento de imágenes con MATLAB", 2016. [Online]. Available at: https://docplayer.es/29680176Introduccion-al-procesamiento-de-imagenescon-matlab-1era-parte.html.

[5] E. Laorden-Fiter, "Descripción, comparación y ejemplos de uso de las funciones de la toolbox de procesado digital de imágenes de MATLAB”, thesis, Escuela Universitaria de Ingeniería, España, 2012.

[6] L. Garcia, "Visión Artificial con MATLAB: Detección y seguimiento de objetos", 2013. [ $\mathrm{O} n \mathrm{li}$ ne $]$. A va i l a b l e a t : https://www.redeweb.com/agenda/visionartificial-con-matlab-deteccion-yseguimiento-de-objetos/.

[7] Escuela Técnica Superior de Ingeniería y Diseño Industrial, "Adquisición de imágenes y entornos gráficos”, 2012. [Online]. Available a http://www.elai.upm.es/moodle/mod/resour ce/view.php?id=147.

[8] P. P. Garcia-García, "Reconocimiento de imágenes utilizando redes neuronales artificiales", thesis MSc., Universidad Complutense de Madrid, España, 2013.

[9] M. Morales, "PC actual", 2014. [Online]. Available at: https://www.pcactual.com/.

[10] Entertainment Software Rating Board, "CALIFICACIONES ESRB", 2016. [Online]. Available at: http://www.esrb.org/ratings. 